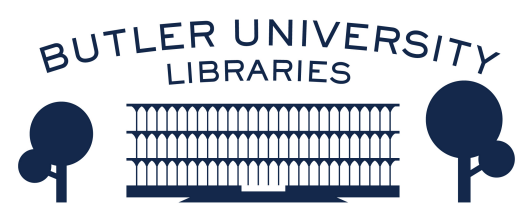

Journal of Hindu-Christian Studies

Volume 20

Article 13

January 2007

\title{
The Methodic of Hindu-Christian Studies
}

Raimon Panikkar

Follow this and additional works at: https://digitalcommons.butler.edu/jhcs

Part of the Religion Commons

\section{Recommended Citation}

Panikkar, Raimon (2007) "The Methodic of Hindu-Christian Studies," Journal of Hindu-Christian Studies: Vol. 20, Article 13.

Available at: https://doi.org/10.7825/2164-6279.1388

The Journal of Hindu-Christian Studies is a publication of the Society for Hindu-Christian Studies. The digital version is made available by Digital Commons @ Butler University. For questions about the Journal or the Society, please contact cbauman@butler.edu. For more information about Digital Commons @ Butler University, please contact digitalscholarship@butler.edu. 


\title{
The Methodic of Hindu-Christian Studies
}

\author{
Raimon Panikkar
}

AFTER more than half a century struggling to find my own identity just following the universal sapiential counsel of "knowing oneself", whereby the self is not just the individual, the new editor of the Journal of Hindu-Christian Studies has put to me the most difficult question to answer in words: "Where do I now stand?". Aware that there are no stupid questions, but certainly silly answers, I take the risk of summarizing my perhaps too many writings on this topic in these few pages, as a tribute to the magnificent task of this Journal, which is a practical example that "splendid isolation" is no longer possible. The "Body of God", to use a South Indian expression, spreads everywhere - as also most Christians would agree. Ultimately, all my writings are autobiographic - not about myself; but trying to give voice to the Self.

My second preamble is to thank Prof. Malkovsky for interrupting me from 'urgent' commitments and plunging me into the more important task of contributing to clarify (I hope) in a single example one of the capital issues of our times from which depend the peace of our planet: the sincere dialogue among cultures and religions. Now the genuine dialogue, which includes love (impossible without mutual knowledge) is not dialectical but "dialogal"; i.e. it transcends the logos. This is precisely religious dialogue, which is ultimately of religions, rightly understood. Religions are not mere sects, but 'that' "ultimate concern" by which we orient our lives.

$* * *$

The Hindu-Christian Studies in general, and not only the studies of the Journal, have been habitually reduced to doctrinal clarifications or to concrete examples of particular cases. Both are very useful and indispensable, but not enough. We still suffer from the impact of times past: Religions equated to doctrines, and studies reduced to merely theoretical approaches - forgetful of the spiritual and practical sense already contained in the word studium, as I am still going to say. Yet, it would be a simplistic reductionism to equate religions with their respective doctrinal contents, which is contrary to the constant claims of the living religions of the people, both Hindu and Christian. Religions are also rituals, ways of life, a certain awareness of human existence and ultimately an experience of reality.

I would like to concentrate myself on one single point which I have synthesized in the awkward idiom of "methodic" instead of "methodology", precisely because I intend to qualify the role of the logos in the study of religion and upgrade the function of the Spirit more in tune. with the traditional tripartite 'anthropology' as a union of body, soul and spirit - sarira, manas, buddhi, whereby the translations are meant to be only "homeomorphic equivalents" and not synonymous concepts. Religions have.doctrines and these are essential but they are also, and mainly, ultimate experiences by which man lives. And, as I have said time and again, institutional religions do not have the monopoly on Religion.

We should learn here from the most

Since the 1960s Raimon Panikkar has been a well-known pioneer in the Hindu-Christian encounter. At present he is Professor Emeritus of Religious Studies of the University of California, where he taught from 1971 to 1987. For the past decade he has been living most of the time in the mountains of Catalunya, Spain attending to his own writings and to seminars in Europe, USA and India, besides being active in Vivarium, a Centre for Crosscultural Studies which he founded. He has published over fifty books and more than three hundred articles from philosophy of science to metaphysics, comparative religion and indology. His most recent work is The Experience of God: Icons of the Mystery (Fortress Press, 2006). 
elementary advice from indian pedagogy which says that the first condition to teach.Sanskrit to Gopal is to know Gopal: contrary to the modern and western procedures, which are mainly concerned to check our theoretical skills. Both are needed: modern objectivity and traditional subjective intentionality.

In this context I have introduced the notion of pisteuma complementing the now classical concept of noêma of phenomenology. Pisteuma is what we believe; noêma what we understand and there is no faith without a certain understanding, nor understanding without a certain faith. Both belong together in an ontonomous relationship. If I follow one religion and my neighbour another one as carrier of the ultimate meaning of life, we do not speak about the same object if we engage in an exclusive doctrinal dialogue unaware of the fact that our respective premises are different. I suspect this is one of the causes of the tragic misunderstandings among religions, which are all the more dangerous, because they are carried in 'good' intention.

Now, faith, which in one way or another, any religion implies, is the awareness that we do not understand everything, that our knowledge is limited and yet that we are conscious of our limits and open to the Infinite. Yet we are conscious of those limits. In this sense faith is the consciousness of our ignorance. On the other hand, because we are also rational creatures, this awareness expresses itself in our rational parameters which we receive from education, culture, personal work and the time in which we live. This is what I call belief. All human beings have faith, although the beliefs that express that faith differ and are often even contradictory. Now, due to cultural factors, while Christianity tends to be identified by beliefs, generally formulated by a "church", Hinduism is not - as I have explained in my book Espiritualidad Hindú. Sanātana dharma.

Now, the "methodic" of Hindu-Christian Studies, as a concrete case of the ambiguously called "Comparative Religion" implies, and I would dare say requires, an empathy which cannot go without a certain kind of conversion whereby I do not mean necessarily a "double belonging", but an intellectual and cordial openness to the spirit of the other religion.
Religion is a human dimension and not an official membership of belonging to a more or less closed group of beliefs and certainly not to any ideology.

We cannot "under-stand" a religion if we, in one way or another, do not "stand-under" the spell of the other religion. To have reduced the doxa of a religion (orthodoxy) to its rational doctrines is a reductionism that no believer could accept. Now, the first hermeneutical rule for "comparative studies" is that the believer in a given religion recognizes oneself in the description the other makes of it - although one may not necessarily agree with the interpretation.

This is only a way of introducing what I am prompted to say. As I have stated several times, religion gives the ultimate meaning to a culture, its more or less concrete sense of life, but culture gives religion its language. Now, languages do not simply give different names to similar objects. Languages are not only different ways of speaking; they are also different ways of thinking, of seeing reality - and therefore they express themselves differently. To know a language is much more than just a question of grammar or vocabulary.

And this is an important point. The modern western genius is characterized by and large by analytical thinking and ultimately ends in classifications. In order to rationally understand we need to distinguish and classify. And in this way we have classified religions. We need, of course, distinctive traits so as to proceed with "clarity". We need to order our thoughts according to hermeneutical clues - the most convenient of which are their doctrinal contents, which are obviously guided by the rational principle of non-contradiction. But this is not the only way to really understand and to enter in deep communion with reality. Experience is also paramount.

The classification has gone so far so as to classify religions and we interpret these devices just as pragmatic expressions of ontological differences (to use a consecrated word).

In order to make it short, I shall simply be personal. People in the trade ask me "what I am" (what a question!), meaning how do I "identify" myself, confusing identity with identification, and interpreting it as classifying myself in the 
already accepted pattern of understanding a person. It is important to remark that the West, by and large, interprets identity (what a thing is) as the "specific difference" (as what a thing isnot) whereas the East as that what a thing so intimately is that it cannot be severed from that is without being destroyed. Brahman is ultimate Reality and thus it has to be immanent, whereas God for the same reason it has to be transcendent, to put just an example.

Coming to my personal reaction, I cannot sincerely answer univocally the otherwise legitimate demand of "what I am". People want to understand me or, at least, where I stand. But a real answer to a person has to be personal, and not just objective as if it were a scientific question. If it is. a "Christian" (again just a label) who asks me, I spontaneously will say yes, that I feel myself Christian and I believe I am such. If a Hindu puts to me the same question, I will equally and sincerely answer yes, that $I$ am a Hindu (as I understand it). Am I then the two 'things' together? On the other hand, if I try to enter into the frame or mind of a certain objectivity I will have to say "No"! - to both questions. What am I then? And the pistol of the "either-or" menaces me. I feel uncomfortable with both answers - because an answer has to take into consideration the person who asks the question. I do not accept the straight jacket of the dictatorship of the Principle of Noncontradiction - that I respect in its proper field, but that I do not absolutize as the universal pattern of intelligibility, as the only field where my consciousness embraces reality - whereby the loving metaphor is appropriate.
I am not criticizing the title of the Journal. I am only asking not to absolutize such concepts as "Hindu" and "Christian" and freeze the dynamism of the words. Religions are living, and thus evoluing realities. I cannot say, according to the Principle of Non-contradiction, that I am a Christian and a non-Christian at the same time. But where on earth is it written, that to be a Christian is to be a non-Hindu -- or a non-buddhist?.

Indeed many doctrines of those traditions are self-contradictory and they cannot to be true at the same time, and under the same presuppositions, etc. But perhaps a breakthrough of this Journal is that it helps us to overcome the "either-or" manner of thinking without falling into contradiction. Religions are dynamic and not only archaeological mummies. We enter into a new Period and this Journal has an important role to play. We are not tied only to the past, nor by the same token to history.

Here I would like to underscore the significance of the word "Studies". I am reminded of the classical description that an authority on the matter used to say: Study (from a root denoting ardour, zeal, passion) means "animi assidua vehemens ad aliquam rem applicata magna cum voluntate occupatio, ut philosophiae, poeticae geometriae, litterarium ..." [a passionate and ardent movement of the spirit, an activity directed to some issue with an intense will, like philosophy ...] (Cicero, $D e$ inventione I, 25). The Hindu-Christian Studies are studium in this sense and as such they have an important contribution to make to the Peace of the world. The venture is worth our effort. 